\title{
Ahí va el señor G de Juan Manuel Chávez
}

\section{Guillermo A. Canteros ${ }^{1}$}

Universidad Nacional del Litoral. Santa Fe, Argentina

guillecant@hotmail.com

ORCID

Citar como: Canteros, G. (2020). Ahí va el señor G de Juan Manuel Chávez. Desde el Sur, 12(1), pp. 347-352.

Con una vasta trayectoria en la gestión editorial, el ámbito de la enseñanza del español como lengua extranjera, la docencia universitaria y la investigación académico-literaria, Juan Manuel Chávez, que nació en Lima (Perú, 1976) y reside actualmente en Barcelona, es en verdad un multifacético hacedor y escritor prolífico. Además de haber participado en numerosas publicaciones colectivas y colaborado en periódicos y revistas editadas en distintos países del continente y España, es autor de los volúmenes de cuentos El rinoceronte que quería ser unicornio (cuentos para niños, Lima, 2017) y Sonríen los desamparados (Santiago de Chile, 2006); de los ensayos Limanerías (Lima, 2012) y Lima. Un camaleonte tra due specchi, con un estudio preliminar de Mario Vargas Llosa (Roma, 2006); del estudio interdisciplinario La Guerra del Pacífico y la idea de nación (Lima, 2010); de la crónica de viaje Latinos y otros peregrinos (Lima, 2013) y de las novelas La derrota de Pallardelle (La edad del olvido) (Lima, 2004), Ahí va el señor $G$ (publicada originalmente en 2009 por editorial Norma y reeditada bajo el sello argentino Campo de Niebla en 2017), El barco de San Martín (Lima, 2016) y la más reciente Cassi, el verano, editada por Planeta (Lima, 2018).

1 Docente-investigador de la Facultad de Humanidades y Ciencias de la Universidad Nacional del Litoral. Integrante del equipo docente de las cátedras Literatura Argentina I, Literatura Hispanoamericana I y del seminario «Arte y cultura en América Latina. Tradiciones, rupturas, procesos» de las carreras de Profesorado y Licenciatura en Letras, así como del «Seminario de literatura argentina» de la carrera de Licenciatura en Enseñanza de la Lengua y la Literatura, y de Literatura Hispanoamericana del bachiller en Letras (ambos correspondientes a UNL Virtual, modalidad a distancia). Coordinador académico y docente de la asignatura electiva Estudios Latinoamericanos: Tensiones, Conflictos, Procesos y de la cátedra abierta de estudios latinoamericanos "José Martí», miembro de la Red Internacional de Cátedras Martianas. En los proyectos de investigación acreditados, ha centrado su interés en el examen de las inscripciones de los discursos sociales en los literarios, la operatividad para el análisis de la narrativa argentina y latinoamericana de categorías como las de género, memoria e identidad, en orden a una lectura renovada de los corpus seleccionados, en diálogo con los enfoques del llamado «giro decolonial». Integra actualmente el equipo responsable del proyecto de investigación CAI+D 2016 «Decolonialismo y configuración genérica de la memoria: conflictos y procesos en la construcción de indianidad en la narrativa latinoamericana actual». 
Cabe destacar que tanto su obra literaria como académica han merecido importantes premios y distinciones; entre ellos, la primera mención del Premio Nacional de Novela Federico Villarreal, el Premio Copé de Plata en cuento, el Premio de la Bienal de Cuento para Niños del ICPNA (Perú) y el Premio de Ensayo de Radio de la Universidad Autónoma de México (UNAM).

Escrita durante la residencia de su autor en la Scuola Superiore per Mediatori Linguistici San Pellegrino (Misano Adriático, Italia), Ahí va el señor G explora, al focalizar en la figura de un poderoso empresario de los medios de comunicación del Perú - el egoísta, cínico y poco escrupuloso señor $\mathrm{G}$-, formas de ruindad y maldad que de manera oblicua nos devuelven como lectores una imagen que obliga a reflexionar sobre nuestro propio cinismo.

Contundente desde un comienzo en su planteo central, la novela inicia con notable concisión y maestría, con párrafos que bien merecen ser reproducidos aquí:

El correo electrónico era de Miss Vivian Nana, única hija del señor Joel, rico comerciante de cacao en Abidjan. El correo electrónico desplegaba un pedido de cuarenta líneas: Por favor, adópteme. $\mathrm{O}$ algo así.

Guardó el mensaje más por intriga que por interés, un tanto cansado de las cadenas de rezos y las preguntas de preocupación que asomaban de todo el mundo en cada correo. Todo el mundo, pues el terremoto que había tenido su epicentro en el mar del Sur, a tres horas de Lima por carretera, se describía con lamentos de incertidumbre en los principales canales de televisión como el punto de partida de una tragedia. Y la tragedia es noticia en cualquier sitio, se dijo un tanto satisfecho, restituyendo uno de los principios básicos de su oficio. Ahí estaban las agencias internacionales dando cuenta del Perú, el Perú, sin distinguir los cientos de kilómetros que median entre una ciudad devastada y otra solamente espantada. Para la mirada extranjera, el Perú es un pañuelo con restos arqueológicos en el Ande y una capital, comprobó otra vez al borrar los mensajes ya contestados, apagando la Mac y encendiendo el plasma que se inclinaba seis o siete grados en la horizontal de la pared. Movida, su ventana multicolor de estreno denotaba desorden. A esa frontera circunscribió el terremoto: Desorden. Desorden por un jarrón, algunos papeles todavía en el piso, la alfombra con cenizas de la tarde. La naturaleza podía ser tan poco creativa a veces.

Por dos minutos se había alborotado la Tierra, ondulando la superficie.

No obstante su escepticismo, cínico incluso, el sismo sí castigó a Lima con consecuencias apremiantes. Incubaba el miedo y dejó una 
estela zigzagueante de rajaduras en la mayoría de construcciones modernas y en las viviendas sociales recién habitadas; además de caos vehicular, cuadros rotos, espejos quebrados y dos o tres vidrios estrellados contra el pavimento desde el piso dieciséis de su edificio. 7,5 en la escala de Richter y un muerto era la estadística para la capital cuatro horas después del siniestro. [...]

Comenzó el desfile de escenas con las noticias del interior. Pisco, Ica, Nasca. La conjetura de una catástrofe. Un millar de cadáveres o desaparecidos como saldo nacional, según los más alharaquientos líderes de la oposición, haciendo de la calamidad un signo de desidia gubernamental. Los terremotos también se reducen a un problema político, especuló el señor G. Las tres ciudades en ruinas. Niños llorando en la intemperie. Muchachitos en primer plano, con los mocos cayendo de la nariz y las bocas contrahechas por el llanto. Lágrimas en vez de ojos. En uno y otro canal, lágrimas. Se le hizo una redundancia tanta miseria. Optó por mirar las paredes blancas de su departamento, limpias a pesar del sismo, sin fotografías a colores ni acuarelas arequipeñas o acrílicos bonaerenses. Limpias no solo de grietas o manchas, sobre todo de referencias a cualquier lazo familiar o cultural. Eran un lienzo concreto donde no existía el trazado ni el boceto. Le encantaba el minimalismo aséptico de su piso. Dos sofás blancos también, la mesa de metal bruñido y el vidrio sin quebrarse. Lámparas blancas y blanco además el aparador para los licores que coleccionaba sin ganas de beber. En la pantalla de cincuenta pulgadas, la vida era negra. No le gustó, y la apagó (Chávez, 2017, pp. 9-10).

Si, por un lado, es en ocasión del sismo de 2007 que sacude su piso en un condominio del distinguido barrio limeño de Miraflores cuando otro sismo (el interior) poco a poco lo saca de eje y lo obliga a confrontarse con recuerdos de su infancia y juventud; por el otro, son esas cavilaciones del protagonista, del juego de la memoria a través de la cual reconstruimos la novela de su vida, las que despliegan la mirada displicente, escéptica y abúlica del señor $G$ para, en definitiva, dibujar una crítica sobre el estado de nuestra propia mirada indolente, fría, inconmovible e imperturbable por momentos, educada por la tecnocracia de los medios de comunicación. Una mirada que introduce la interrogante acerca de cómo los espectadores contribuimos, mediante nuestro consumo de mercancías, de espectáculos y de protestas, al reino infame de la equivalencia mercantil.

Hoy, cuando las básicas maniobras de choque han sido cooptadas por el mercado; cuando la oposición transgresora y el experimentalismo innovador, así como el impacto, el escándalo y la obscenidad, han sido tomados y domados por las pantallas, las vitrinas y los escenarios globales, no llama la atención que los espectadores nos hayamos convertido en los «monstruos más fríos». 
Todo lo que asombra, excita o conmueve, vende. Vende en cuanto su conflicto se consume en su propia expectación, sin dejar residuos. La disidencia vende, porque vende lo marginal domesticado, en la medida en que impresiona sin perturbar ni comprometer, sorprende sin interpelar, sin levantar cuestiones ni dejar pendiente la pregunta por lo que no está (Escobar, 2015).

El señor G sabía muy bien que por esas razones se dedicaba a la televisión satelital. Acechando el ambiente con la misma destreza que el lobo imprime a su instinto para cazar al conejo, su comprensión de los otros no era racional; era lo único que en su vida no se sujetaba a construcciones cognitivas, la asumía como una pulsión íntima y esencial, al igual que olfatear o degustar. El señor $\mathrm{G}$ paladeaba sus motivaciones empresariales como un predador pasa la lengua por la piel caliente y muerta de su presa. Desde antes de la universidad había sospechado con eficacia que la gente ya nunca iba a buscar la verdad en las pantallas; prefería que le cuenten una falsedad mágica incluso en los noticieros. En la simulación estaba el negocio, y sus programas actuales, espectados por millones, eran la prueba ruidosa de su éxito. Toda vez que la audiencia detectaba que tras un logro ajeno o una desdicha colectiva se agazapaba el afán de objetividad informativa, la misma audiencia se marchaba, buscando otro canal. En cambio, exagerar el mérito o llevar a melodrama los problemas atrapaba a cualquiera por la calidad de la persuasión. Cada espectador sabía que la niña sin padres y exhausta hasta la inanición, que daba su testimonio en el programa familiar del sábado, era una farsa. Cada espectador lo sabía, pero igual se encandilaba. El asunto radica en mentir con desenvoltura, expuso cuatro meses atrás en un seminario académico. Así, la mentira no tiene los lastres del engaño; se vuelve un pacto. Lo aplaudieron unos cuantos.

En cierta medida, el señor $\mathrm{G}$ advertía que la verdad y todas sus implicancias habían perdido espacio en la discusión natural de las gentes. Era un anacronismo sin prestigio.

Así, resulta consustancial a esta lógica el apotegma del señor G: «Comerciaremos con la ficción de la realidad». La capacidad de recibir estímulos fuertes depende, en cada receptor contemporáneo, de su incapacidad para ser fácilmente conmovido. Lo explícito pertenece a la imagen: es lo que se mira porque alguien lo deja ver y lo que se deja ver porque otro quiere y puede mirarlo (Schwarzböck, 2017). Es eso lo que parece querer decirnos el señor G: se necesitan dos sujetos para que haya explicitud: uno que la autoriza (el que deja ver: la autoridad) y otro que la disfruta (el que quiere y puede mirar: el espectador).

Con la excusa de que vemos al señor $\mathrm{G}$ mirar, somos nosotros -en definitiva-los mirados y, sobre todo, examinados por el texto. 
Ahora bien, lo que a una persona le «gusta» mirar desde el lugar del espectador no dice nada — absolutamente nada - sobre su psicología. Y es que las imágenes explícitas están pensadas para un sujeto que les pertenece, que ellas mismas han subido al escenario. De allí la inteligencia de la prosa de Juan Manuel Chávez: nos habla del cinismo del señor G, nos habla del cinismo que anida en nuestra mirada; pero, en verdad, nos habla de un régimen de visibilidad que regula la subjetividad de la época sobre la base de una paradoja: un régimen de visibilidad que muestra pero no deja ver.

Es en ese pasaje de hacer visible lo invisible que el gesto de Juan Manuel Chávez se convierte en un acto de disenso y adquiere una connotación política. Un gesto disensual que perturba el orden del imaginario hegemónico, crea nuevas formas de experiencia de lo sensible, nuevas distancias con las configuraciones existentes de lo dado.

Ahí va el señor $G$, una obra cuyo valor no reside tanto en su novedad como en su contemporaneidad. En el juego de distancia y a la vez cercanía se define la contemporaneidad, nos dice Giorgio Agamben (2011). Contemporáneo, y Juan Manuel Chávez lo es con holgura, es aquel que mantiene la mirada fija en su tiempo, para percibir no sus luces, sino su oscuridad. Contemporáneo es, justamente, aquel que sabe ver esa oscuridad, aquel que está en condiciones de escribir humedeciendo la pluma en la tiniebla del presente.

Es esa distancia la que inscribe la contemporaneidad en la escritura de nuestro autor en cuestión y lo ubica decididamente en un lugar destacado de lo que llamamos «literatura latinoamericana contemporánea».

Como diría otro peruano, Diego Trelles Paz, en la antología El futuro no es nuestro. Nueva narrativa latinoamericana (2011): «Come and see, querido lector; ven y mira, que aquí estamos: de espaldas al futuro, narrando el derrumbe» (p. 27).

$Y$ es que, alejado de gestos pedagogizantes o pontificantes, Allí va el señor $G$ es por cierto un artefacto en el que cada mecanismo narrativo está dispuesto para ser, al mismo tiempo, narrativamente efectivo y éticamente justo. 


\section{REFERENCIAS BIBLIOGRÁFICAS}

Agamben, G. (2011). ¿Qué es lo contemporáneo? En Desnudez. Buenos Aires: Adriana Hidalgo Editora.

Chávez, J. M. (2017). Ahí va el señor G. Buenos Aires: Campo de Niebla Editorial.

Escobar, T. (2015). La irrepetible aparición de la distancia. Una defensa política del aura. En Imagen e intemperie. Las tribulaciones del arte en los tiempos del mercado total. Buenos Aires: Capital Intelectual.

Schwarzböck, S. (2017). Los monstruos más fríos. Estética después del cine. Buenos Aires: Mardulce.

Trelles Paz, D. (2011). Prólogo. En El futuro no es nuestro. Nueva narrativa latinoamericana. Buenos Aires: Eterna Cadencia. 